\title{
Microbe-Endocrine Hormone Interactions
}

\author{
Shamim Al-Husseini, Abdalla Hamed and Primrose Freestone*
}

Department of Infection, Immunity and Inflammation, University Road, UK

Submission: October 10, 2017; Published: December 14, 2017

*Corresponding author: Primrose Freestone, Department of Infection, Immunity and Inflammation, Maurice Shock Medical Sciences Building, University of Leicester, University Road, Leicester LE1 9HN UK, Tel: +44 (0)116-252-5656; Fax: +44 (0)116-252-5030; Email: ppef1@le.ac.uk

\section{Introduction}

The influence of hormones on human cells is very well characterized, yet much less understood is the response to those chemical signals of the 1013-1014 bacteria and fungi that are coresident within the human frame [1]. Microbial Endocrinology is a research area which seeks to understand the role of microbial interactions with mammalian hormones in conditions of health and disease [2-4]. It takes the view that through their long evolutionary relationship with animals microorganisms have evolved systems for sensing hormones which they use as an indicator that they are within the proximity of a potential host. This article considers what happens when the human microbiota

Table 1: Hormone responsive microorganisms. come into contact with the chemical signals of their host, and the health significance of this inter-kingdom-encounter.

Hormones can be classified on the basis of their chemical structures: amino acid, peptide and protein and cholesterol based, and the receptor location by which the hormonal signal is transduced. The function of each hormonal type will be described, and the health implications to the host when the hormone is encountered by potentially infectious bacteria and fungi. Structures of the hormones covered and the microbes which recognize them can be found in Table 1, respectively [539].

\begin{tabular}{|c|c|c|c|c|}
\hline Species & Hormone/Metabolite & Growth & Virulence & Reference \\
\hline Aeromonas hydrophila & $\mathrm{NE}$ & + & + & Kinney et al. [5] \\
\hline Acinetobacter lwoffii & $\mathrm{NE}$ & + & & Freestone et al. [6] \\
\hline Bordetella bronchiseptica,B. pertussis & NE, Adr, Dop & + & + & Anderson \& Armstrong [7] \\
\hline Borrelia burgdorferi & NE & & + & Scheckelhoff et al. [8] \\
\hline Brachyspira pilosicoli & $\mathrm{NE}$ & + & + & Naresh \& Hampson [9] \\
\hline Campylobacter jejuni & $\mathrm{NE}$ & + & + & Cogan et al. [10] \\
\hline Citrobacterfreundii, C. rodentium & $\mathrm{NE}$ & + & & $\begin{array}{l}\text { Freestone et al. [6], Bailey et al. } \\
\text { [11] }\end{array}$ \\
\hline Enterobacter agglomerans, E. sakazaki & $\mathrm{NE}$ & + & & Freestone et al. [6] \\
\hline Enterococcus faecalis, E. cloacae & $\mathrm{NE}$ & + & & Freestone et al. [6] \\
\hline Escherichia coli (commensal and pathogenic) & $\begin{array}{l}\text { NE, Adr, Dop, Iso, Dob, } \\
\text { DHPG, DHMA }\end{array}$ & + & + & $\begin{array}{c}\text { Lyte \& Ernst [12], Freestone et } \\
\text { al. [6,13-15], Green et al. [16], } \\
\text { Vlisidou et al. [17], Sandrini et al. } \\
\text { [18] }\end{array}$ \\
\hline Hafnia alvei & $\mathrm{NE}$ & + & & Freestone et al. [6] \\
\hline Helicobacter pylori & $\mathrm{NE}$ & + & & Doherty et al. [19] \\
\hline Klebsiella oxytoca, K. pneumoniae & $\mathrm{NE}$ & + & & Freestone et al. [6] \\
\hline Listeria monocytogenes & NE, Adr, Dop & + & & $\begin{array}{c}\text { Coulanges et al. [20], Freestone } \\
\text { et al. [6] }\end{array}$ \\
\hline Morganella morgana & $\mathrm{NE}$ & + & & Freestone et al. [6] \\
\hline Mycoplasma hyponeumoniae & $\mathrm{NE}$ & & + & O’Neal et al. [21] \\
\hline Proteus mirabilis & NE & + & & Freestone et al. [6] \\
\hline
\end{tabular}




\section{Journal of Endocrinology and Thyroid Research}

\begin{tabular}{|c|c|c|c|c|}
\hline Pseudomonas aeruginosa & NE, Adr, Dop & + & + & $\begin{array}{c}\text { Alverdy et al.[22], Freestone et al. } \\
{[6,23]}\end{array}$ \\
\hline Salmonella enterica, Salmonella Typhimurium & NE, Adr, Dop & + & + & $\begin{array}{l}\text { Freestone et al. [6,24] Methner et } \\
\text { al. [25], Pullinger et al. [26] }\end{array}$ \\
\hline Shigella sonnei, S. flexneri & $\mathrm{NE}$ & + & & Freestone et al. [6,27] \\
\hline Staphylococcus aureus & NE, Dop & + & & Freestone et al. [27] \\
\hline \multicolumn{5}{|l|}{ Staphylococcus epidermidis, S. capitis, } \\
\hline S. saprophyticus, S. haemolyticus, S. hominis & NE, Adr, Dop, Iso, Dob & + & + & Freestone et al. $[6,27]$ \\
\hline Streptococcus dysgalactica & NE & + & & Freestone et al. [6] \\
\hline $\begin{array}{c}\text { Vibrio parahaemolyticus, V. mimicus, V. vulnifi- } \\
\text { cus }\end{array}$ & NE, Adr, Dop & + & + & Nakano et al. [28] \\
\hline Xanthomonas maltophila & NE & + & & Freestone et al. [6] \\
\hline Yersinia enterocolitica & NE, Adr, Dop, & + & & Freestone et al. [6,29] \\
\hline Periodontal pathogens & NE, Adr & + & & Roberts et al. [30] \\
\hline \multicolumn{5}{|l|}{$\begin{array}{c}\text { Actinomyces gerenscseriae, A. naeslundii, A. } \\
\text { odontolyticus, Campylobacter gracilis, Capno- } \\
\text { cytophaga sputigena, C. gingivalis, Eikenella } \\
\text { corrodens, Eubacterium saburreum, Fusobacteri- } \\
\text { um periodonticum, F. nucleatum subsp. Vincentii, } \\
\text { Leptotrichia buccalis, Neisseria mucosa, Pepto- } \\
\text { streptococcus anaerobius, P. micros, Prevotella } \\
\text { denticola, P. Melaninogenica, S. intermedius, S. } \\
\text { gordonii, S. constellatus, S. mitis, S. mutans, S. } \\
\text { sanguis }\end{array}$} \\
\hline Burkholderia pseudomallei & Insulin & & + & Wood et al. [31] \\
\hline Candia albicans & Oestrogen & & & \\
\hline \multicolumn{5}{|l|}{ Progesterone } \\
\hline Luteinising hormone & + & & & \\
\hline+ & + & & & \\
\hline \multicolumn{5}{|l|}{+} \\
\hline+ & $\begin{array}{l}\text { Kinsman et al. [32], } \\
\text { White \& Larsen [33], } \\
\text { Tarry et al. [34] }\end{array}$ & & & \\
\hline \multicolumn{5}{|l|}{ Banerjee et al. [35] } \\
\hline \multicolumn{5}{|l|}{ Bramley et al. [36,37] } \\
\hline Chlamydia trachomatis & Oestrogen & & & \\
\hline Progesterone & & + & & \\
\hline+ & Sonnex [38] & & & \\
\hline \multicolumn{5}{|l|}{ Sonnex [38] } \\
\hline E. coli & ACTH & & + & Schreiber \& Brown [39] \\
\hline
\end{tabular}

The ' + ' indicates that the hormone shown, or their metabolites have induced enhancement of growth or virulence of the bacterial species shown. Key: NE, noradrenaline; Adr, adrenaline; Dop, dopamine; Iso, isoprenaline; Dob, dobutamine; DHPG, dihydroxy phenylglycol; DHMA, dihydroxy mandelic acid, ACTH, adrenocorticotrophic hormone.

This table was adapted with permission from Freestone [3].

\section{Amino Acid-Derived Hormones}

These are commonly derived from dietary tyrosine and tryptophan, and comprise two main types: thyroid hormone such as thyroxine and the catecholamines dopamine, noradrenaline and adrenaline [5]. Catecholamines are well studied as they possess a diversity of signaling functions and are widely distributed throughout the tissues and organs of the human body [5]. Noradrenaline and adrenaline are neurotransmitters but also play an integral role in the flight or fight response. In terms of the infection significance of catecholamine release, the field of psychoneuroimmunology has long reported that stress hormone elevations in humans and animals increases their risk of developing an infection. This is in part due to 
stress-released catecholamine and glucocorticoid hormones reducing the functionality of the immune system [6,7]. More recently, Microbial Endocrinology studies have shown that like immune cells many bacteria involved in human infections recognize catecholamines which they appear to use as an indicator that their host is stressed, and possibly less able to mount a defense to the invading microbe $[3,4]$. Table 1 shows the catecholamine-responsive microbes that have been identified so far. Most analyses of bacterial stress hormone interactions have looked at growth effects using serum- or blood-based culture media, chosen to more closely reflect the host environment in which the hormone will be encountered [40]. Blood or serum containing media is iron limited due to the presence of ferric iron sequestering proteins such as transferrin or lactoferrin which inhibits the growth of most bacterial pathogens [41]. Because iron is so essential for the in-vivo growth of bacteria [42], its limitation by transferrin and lactoferrin represents a key immune defense against infection. However, bacteria can directly use catecholamines as a kind of siderophore to steal transferrin and lactoferrin Fe which enables up to 100,000-fold increases in bacterial cell numbers in what normally should be highly bacteriostatic host tissue fluids $[14,15,18,23]$.

Dopamine, noradrenaline and adrenaline exposure can also induce pathogenic bacteria to become even more virulent by inducing expression of genes in toxin release [43], increasing biofilm formation [18] and enhancing attachment to host epithelial tissues [16,17]. Catecholamines can even catalyze recovery of bacteria severely damaged by antibiotic treatment $[18,27]$, and rapidly promote exchange of genetic material between different bacterial species [44]. In terms of the infection significance of catecholamine-microbe interactions, catecholamines are used therapeutically in acutely ill patients to maintain heart and kidney function [5]. Catecholamines at the levels infused down intravenous catheter lines were found to massively increase staphylococcal biofilm formation on the same plastic, while clinically attainable levels of catecholamines also increased $P$. aeruginosa biofilm formation on endotracheal tubing (used to maintain an open airway in ventilated patients) as well as enabling the pathogen to resist antibiotic treatment [18].

\section{Peptide and Protein Hormones}

There are reports of peptide-like hormones affecting the infectious potential of pathogenic bacteria. Melioidosis is an infectious disease caused by the Gram-negative bacterium Burkholderia pseudomallei, which tends to be found in soil and water of tropical climates such as Vietnam and parts of Australia. It has been observed that type I diabetes mellitus is an apparent risk factor for the development of the septicemic form of melioidosis [20]. Woods and co-workers found that $B$. pseudomallei can directly bind human insulin and that each bacterial cell expressed around 5000 surface-associated insulin receptors. Woods et al. [31] showed that insulin inhibited the growth of B. pseudomallei and suggested that the deficiency of the hormone at least in part explained the higher risk of melioidosis in insulin-dependent diabetics [31].

Adrenocorticotropic hormone (ACTH) is a peptide hormone that induces the adrenal cortex to produce corticosteroid hormones such as cortisol which contribute to regulation of systemic glucose levels. It is therefore interesting that Schreiber and Brown found that exposure to ACTH increased attachment of E. coli 0157:H7 to gut epithelia, though the underlying mechanism for this response is not clear [39]. Thyrotropin is a pituitary hormone that induces the thyroid gland to produce thyroxine followed by triiodothyronine which stimulates oxidative respiration and organ development. Interestingly, use of radiolabelled thyrotropin has showed the presence of receptor for thyrotropin in Yersinia enterocolitica [45,46]. The thyrotropin specificity of the Yenterocolitica binding activity was similar to that of the thyrotropin receptor in human thyroid tissue. This binding activity is thought to have implications for Graves' disease, which is an autoimmune disease in which thyroid-stimulating antibodies to the thyroid-stimulating hormone receptor mimic thyroid-stimulating hormone, which activates the receptor leading to hyperthyroidism. Thyrotropin binding sites on have been shown to be recognized by antibodies from humans with Graves' disease, and prior infection by $Y$. enterocolitica has been implicated in the pathogenesis of Graves' disease [46]. The outer membrane porins $0 \mathrm{mp} \mathrm{A,C}$ and $\mathrm{F}$ have been identified as the $Y$. enterocolitica targets recognized by Graves' patient antibodies, though their role in contributing to development of Graves' disease remains to be shown [47].

Candida albicans is a dimorphic opportunistic fungal pathogen of females and the immunocompromised which has been shown to interact with several human peptide hormones. Luteinizing hormone is required for ovulation and the formation of a corpus luteum in the female menstrual cycle. C. albicans has been shown to bind human luteinizing hormone and chorionic gonadotropin [36]. Bramley et al. [36] used (125I)-labeled luteinizing hormone and chorionic gonadotropin to demonstrate the presence of specific binding sites for both hormones in $C$. albicans, and C. tropicalis [36]. The binding activity was found to be highly specific and was not surface associated instead being at greatest levels in microsomes and cytoplasmic fractions. Also, of considerable relevance to $C$. albicans infectivity, interaction with the luteinizing hormone was found to stimulate germination of Candida spores and germ tube formation [32].

\section{Cholesterol-Derived Hormones}

Cholesterol is the chemical basis of steroid hormones such as oestrogen, progesterone and testosterone which regulate aspects of the metabolism, tissue differentiation and reproductive cycles of females and males. Investigations from a variety of researchers have shown that exposure of some bacteria and fungi to steroid hormones can elevate infection risk in certain patient groups. For instance oestrogen have been shown to increase the likelihood of urogenital infections, particularly during 
pregnancy, or in women taking high oestrogen contraceptives or hormone replacement therapy [38]. Chlamydia trachomatis is an important sexually transmitted pathogen, especially in young women; Sonnex [38] reported that treatment of C. trachomatis with physiological levels of oestrogen increased infection of human endometrial cells, and enhanced Chlamydia colonisation of female mice. C. trachomatis infection of female mice was also increased following pre-treatment with progesterone. C. albicans is a major source of fungal infections in women of reproductive age [38] which has been shown to possess an oestrogen binding protein of high affinity and specificity $[32,33,34]$. Contact with oestrogen has been reported to increase $C$. albicans growth as well as its infectivity, causing the yeast to shift into to a more invasive hyphal morphology [33]. Tarry et al. [34] showed that C. albicans vaginal colonization in a rat model of infection was increased over 8-fold when a physiological level of oestrogen was present [38]. Banerjee et al. [35] investigated the effects of progesterone on C. albicans gene expression and found that expression of 99 genes was differentially affected by the hormone. Most changes were metabolism associated such as protein synthesis and cellular transport. Of relevance to infection risk was the finding that expression of virulence associated genes such as those involved in hyphal induction, pathogenesis and multi-drug resistance genes were significantly increased in progesterone-treated Candida [48-50].

\section{Conclusion}

The effects of endogenous hormones on mammalian cell are well understood, yet although microbes within the human body will repeatedly encounter their host hormones the biological significance to the host of these interactions is only now becoming apparent. This review examined only a few of the many hormones within the human body, but still revealed that there are considerable health implication for some of the microbehormone encounters. Table 1 revealed that the most extensively studied area of microbial endocrinology is catecholaminerelated, largely because of the long held view of stress increasing infection risk. However it is clear that other types of contact the human microbiota may have with mammalian hormones has health implications. It will be interesting to discover if additional signals within our hormonal milieu are being sensed by the thousands of other species of microbes we host.

\section{Acknowledgement}

SA gratefully acknowledges the funding of the Iraqi Government High Committee Education Development in Iraq HCED. AH acknowledges the support of the Ministry of Higher Education, Libyan Government.

\section{References}

1. Sekirov I, Russell SL, Antunes LC, Finlay BB (2010) Gut microbiota in health and disease. Physiol Rev 90(3): 859-904.

2. Lyte M (2004) Microbial endocrinology and infectious disease in the $21^{\text {st }}$ century. Trends Microbiol 12(1): 14-20.
3. Freestone P (2013) Communication between bacteria and their hosts. Scientifica 2013: 361073.

4. Sandrini S, Aldriwesh M, Alruways M, Freestone P (2015) Microbial endocrinology: host-bacteria communication within the gut microbiome. J Endocrinol 225(2): R21-R34.

5. Kinney KS (1999) Catecholamine enhancement of Aeromonas hydrophila growth. Microbial pathogenesis 26(2): 85-91.

6. Freestone PP, Haigh RD, Williams PH, Lyte M (1999) Stimulation of bacterial growth by heat-stable, norepinephrine-induced autoinducers. FEMS Microbiol Lett 172(1): 53-60.

7. Anderson MT, Armstrong SK (2006) The Bordetella bfe system: growth and transcriptional response to siderophores, catechols, and neuroendocrine catecholamines. J Bacteriol 188(16): 5731-5740.

8. Scheckelhoff MR, Telford SR, Wesley M, Hu LT (2007) Borrelia burgdorferi intercepts host hormonal signals to regulate expression of outer surface protein A. Proc Natl Acad Sci U S A 104(17): 7247-7252.

9. Naresh R, Hampson DJ (2011) Exposure to norepinephrine enhances Brachyspira pilosicoli growth, attraction to mucin and attachment to Caco-2 cells. Microbiology 157(2): 543-547.

10. Cogan TA, Thomas AO, Rees LE, Taylor AH, Jepson MA, et al. (2007) Norepinephrine increases the pathogenic potential of Campylobacter jejuni. Gut 56(8): 1060-1065.

11. Bailey MT, Dowd SE, Parry NM, Galley JD, Schauer DB, et al. (2010) Stressor exposure disrupts commensal microbial populations in the intestines and leads to increased colonization by Citrobacter rodentium. Infect Immun 78(4): 1509-1519.

12. Lyte M, Ernst S (1993) Alpha and beta adrenergic receptor involvement in catecholamine-induced growth of gram-negative bacteria. Biochem Biophys Res Commun 190(2): 447-452.

13. Freestone PP, Williams PH, Haigh RD, Maggs AF, Neal CP, et al. (2002) Growth stimulation of intestinal commensal Escherichia coli by catecholamines: a possible contributory factor in trauma-induced sepsis. Shock 18(5): 465-470.

14. Freestone PP, Lyte M, Neal CP, Maggs AF, Haigh RD, et al. (2000) The mammalian neuroendocrine hormone norepinephrine supplies iron for bacterial growth in the presence of transferrin or lactoferrin. J Bacteriol 182(21): 6091-6098.

15. Freestone PP, Haigh RD, Williams PH, Lyte M (2003) Involvement of enterobactin in norepinephrine-mediated iron supply from transferrin to enterohaemorrhagic Escherichia coli. FEMS microbiology letters 222(1): 39-43.

16. Green BT, Lyte M, Chen C, Xie Y, Casey MA, et al. (2004) Adrenergic modulation of Escherichia coli 0157: H7 adherence to the colonic mucosa. Am J Physiol Gastrointest Liver Physiol 287(6): G1238-G1246.

17. Vlisidou I, Lyte M, van Diemen PM, Hawes P, Monaghan P, et al. (2004) The neuroendocrine stress hormone norepinephrine augments Escherichia coli 0157: H7-induced enteritis and adherence in a bovine ligated ileal loop model of infection. Infect Immun 72(9): 5446-5451.

18. Sandrini SM, Raminder S, Jonathan W, Remya M, Richard DH, et al. (2010) Elucidation of the mechanism by which catecholamine stress hormones liberate iron from the innate immune defense proteins transferrin and lactoferrin. Journal of bacteriology 192(2): 587-594.

19. Doherty NC, Tobias A, Watson S, Atherton JC (2009) The Effect of the Human Gut-Signalling Hormone, Norepinephrine, on the Growth of the Gastric Pathogen Helicobacter pylori. Helicobacter 14(3): 223-230.

20. Coulanges V, Andre P, Vidon DJM (1998) Effect of Siderophores, Catecholamines, and Catechol Compounds on Listeria spp. Growth in Iron-Complexed Medium. Biochemical and biophysical research communications 249(2): 526-530. 
21. Oneal MJ, Schafer ER, Madsen ML, Minion FC (2008) Global transcriptional analysis of Mycoplasma hyopneumoniae following exposure to norepinephrine. Microbiology 154(9): 2581-2588.

22. Alverdy J, Holbrook C, Rocha F, Seiden L, Wu RL, et al. (2000) Gutderived sepsis occurs when the right pathogen with the right virulence genes meets the right host: evidence for in vivo virulence expression in Pseudomonas aeruginosa. Ann Surg 232(4): 480-489.

23. Freestone PP, Hirst RA, Sandrini SM, Sharaff F, Fry H et al. (2012) Pseudomonas aeruginosa-catecholamine inotrope interactions: a contributory factor in the development of ventilator-associated pneumonia? Chest 142(5): 1200-1210.

24. Freestone PP, Haigh RD, Lyte M (2007) Blockade of catecholamineinduced growth by adrenergic and dopaminergic receptor antagonists in Escherichia coli 0157: H7, Salmonella enterica and Yersinia enterocolitica. BMC Microbiol 7(1): 8.

25. Methner U, Rabsch W, Reissbrodt R, Williams PH (2008) Effect of norepinephrine on colonisation and systemic spread of Salmonella enterica in infected animals: role of catecholate siderophore precursors and degradation products. Int J Med Microbiol 298(5): 429-439.

26. Pullinger GD, Sonya CC, Fathima FS, Pauline MD, Francis D, et al. (2010) Norepinephrine augments Salmonella enterica-induced enteritis in a manner associated with increased net replication but independent of the putative adrenergic sensor kinases QseC and QseE. Infection and immunity 78(1): 372-380.

27. Freestone PP, Haigh RD, Lyte M (2008) Catecholamine inotrope resuscitation of antibiotic-damaged staphylococci and its blockade by specific receptor antagonists. J Infect Dis 197(7): 1044-1052.

28. Nakano M, Takahashi A, Sakai Y, Nakaya Y (2007) Modulation of pathogenicity with norepinephrine related to the type III secretion system of Vibrio parahaemolyticus. J Infect Dis 195(9): 1353-1360.

29. Freestone PP, Haigh RD, Lyte M (2007) Specificity of catecholamineinduced growth in Escherichia coli 0157: H7, Salmonella enterica and Yersinia enterocolitica. FEMS microbiology letters 269(2): 221-228.

30. Roberts A, Matthews JB, Socransky SS, Freestone PP, Williams PH, et al. (2002) Stress and the periodontal diseases: effects of catecholamines on the growth of periodontal bacteria in vitro. Oral Microbiol Immunol 17(5): 296-303.

31. Woods D, Jones A, Hill PJ (1993) Interaction of insulin with Pseudomonas pseudomallei. Infect Immun 61(10): 4045-4050.

32. Kinsman O, Pitblado K, Coulson CJ (1988) Effect of Mammalian Steroid Hormones and Luteinizing Hormone on the Germination of Candida albicans and Implications for Vaginal Candidosis./; Die Wirkung von Säugersteroidhormonen und Gelbkörperreifungshormon auf die Keimschlauchbildung von Candida albicans und ihre Bedeutung für die Vaginalcandidose. Mycoses 31(12): 617-626.

33. White S, Larsen B, (1997) Candida albicans morphogenesis is influenced by estrogen. Cell Mol Life Sci 53(9): 744-749.

34. Tarry W, Fisher M, Shen S, Mawhinney M (2005) Candida albicans: the estrogen target for vaginal colonization. J Surg Res 129(2): 278-282.
35. Banerjee D, Martin N, Nandi S, Shukla S, Dominguez A, et al. (2007) A genome-wide steroid response study of the major human fungal 8 pathogen Candida albicans. Mycopathologia 164(1): 1-17.

36. Bramley TA, Menzies GS, Williams RJ, Adams DJ, Kinsman OS (1990) Specific, high-affinity binding sites for human luteinizing hormone (hLH) and human chorionic gonadotrophin (hCG) in Candida species. Biochem Biophys Res Commun 167(3): 1050-1056.

37. Bramley T, Menzies GS, Williams RJ, Kinsman OS, Adams DJ (1991) Binding sites for LH in Candida albicans: comparison with the mammalian corpus luteum LH receptor. J Endocrinol 130(2): 177-190.

38. Sonnex C (1998) Influence of ovarian hormones on urogenital infection. Sex Transm Infect 74(1): 11-19.

39. Schreiber KL, Brown DR (2005) Adrenocorticotrophic hormone modulates Escherichia coli 0157: H7 adherence to porcine colonic mucosa. Stress 8(3): 185-190.

40. Li W, Lyte M, Freestone PP, Ajmal A, Colmer HJA, et al. (2009) Norepinephrine represses the expression of tox A and the siderophore genes in Pseudomonas aeruginosa. FEMS Microbiol Lett 299(1): 100109.

41. Lambert LA, Perri H, Halbrooks PJ, Mason AB (2005) Evolution of the transferrin family: conservation of residues associated with iron and anion binding. Comp Biochem Physiol B Biochem Mol Biol 142(2): 129141.

42. Ratledge C, Dover LG (2000) Iron metabolism in pathogenic bacteria. Annu Rev Microbiol 54: 881-941.

43. Lyte M, Erickson AK, Arulanandam BP, Frank CD, Crawford MA, et al. (1997) Norepinephrine-induced expression of the K99 pilus adhesin of enterotoxigenic Escherichia coli. Biochem Biophys Res Commun 232(3): 682-686.

44. Peterson G, Kumar A, Gart E, Narayanan S (2011) Catecholamines increase conjugative gene transfer between enteric bacteria. Microb Pathog 51(1-2): 1-8.

45. Weiss M, Ingbar SH, Winblad S, Kasper DL (1983) Demonstration of a saturable binding site for thyrotropin in Yersinia enterocolitica. Science 219(4590): 1331-1333.

46. Heyma P, Harrison L, Robins BR (1986) Thyrotrophin (TSH) binding sites on Yersinia enterocolitica recognized by immunoglobulins from humans with Graves' disease. Clin Exp Immunol 64(2): 249-254.

47. Hargreaves CE, Grasso M, Hampe CS, Stenkova A, Atkinson S, et al. (2013) Yersinia enterocolitica provides the link between thyroidstimulating antibodies and their germline counterparts in Graves' disease. J Immunol 190(11): 5373-5381.

48. Goldstein DS, Eisenhofer G, Kopin IJ (2003) Sources and significance of plasma levels of catechols and their metabolites in humans. I Pharmacol Exp Ther 305(3): 800-811.

49. Reiche EMV, Nunes SOV, Morimoto HK (2004) Stress, depression, the immune system, and cancer. Lancet Oncol 5(10): 617-625.

50. Glaser R, Kiecolt GJK (2005) Stress-induced immune dysfunction: implications for health. Nat Rev Immunol 5(3): 243-251. 
Your next submission with Juniper Publishers will reach you the below assets

- Quality Editorial service

- Swift Peer Review

- Reprints availability

- E-prints Service

- Manuscript Podcast for convenient understanding

- Global attainment for your research

- Manuscript accessibility in different formats

( Pdf, E-pub, Full Text, Audio)

- Unceasing customer service

Track the below URL for one-step submission https://juniperpublishers.com/online-submission.php 